\title{
Influence of the type of fat and air humidity on chosen properties of the lipid fraction in the process of baking shortbread pastries
}

\author{
By K. Miśkiewicz $^{a, *}$, E. Nebesny ${ }^{a}$, J. Rosicka-Kaczmarek ${ }^{a}$, G. Budryn ${ }^{a}$ and W. Krysiak ${ }^{a}$ \\ ${ }^{a}$ Institute of Chemical Technology of Food, Faculty of Biotechnology and Food Sciences, \\ Lodz University of Technology, 4/10 Stefanowskiego Street, 90- 924 Lodz, Poland \\ * Corresponding author: karolina.miskiewicz@ tlen.pl
}

\begin{abstract}
RESUMEN
Influencia del tipo de grasa y humedad en el proceso de horneado de mantecadas sobre determinadas propiedades de la fracción lipídica

Los resultados de este estudio demuestran que el tipo de grasa utilizada en el horneado de mantecadas tienen una influencia evidente en las propiedades de la fracción lipídica y una correlación entre estas propiedades (acidez, peróxidos, dienos y trienos conjugados).

Para grasas bajas en trans la correlación entre la acidez y el índice de peróxido es inversamente proporcional, para grasas conteniendo trans esta correlación fue directamente proporcional.

Un aumento de la humedad del aire durante el horneado causa una disminución de la temperatura de fusión de las fracciones de grasas utilizadas en el proceso, en comparación con las grasas de repostería horneadas en aire seco. Esto puede indicar la presencia de productos con alto grado de insaturación en las fracciones lipídicas.
\end{abstract}

PALABRAS CLAVE: Dienos conjugados y trienos - DSC - Índice de acidez - Índice de peróxidos.

\section{SUMMARY}

Influence of the type of fat and air humidity on chosen properties of the lipid fraction in the process of baking shortbread pastries

The results from his study reveal that the type of fat used during the baking of shortbreads had a noticeable influence on the properties of lipid fractions as well as the correlation among these properties (acid value, peroxide value, conjugated dienes and trienes contents).

For low-trans fats, the correlation between acid value and peroxide value was inversely proportional; for transcontaining fats this correlation was directly proportional.

An increase in air humidity during baking caused a decrease in the melting temperature of the fractions of fats used in the process, compared to fats from pastries baked in dry air. This may be indicative of a product with a high degree of unsaturation in the lipid fraction.

KEY-WORDS: Acid value - Conjugated dienes and trienes - DSC-Peroxide value.

\section{INTRODUCTION}

Fat, after flour and sugar, is one of main raw materials used for the preparation of pastries
(Manche-Rezzoug et. al., 2002). Fats are a structure-forming factor in the production of a majority of cakes and confectionery as well as a carrier of aroma and taste (Zoulias et al., 2002). The selection of the appropriate type of fat determines the properties of products during production (viscosity, aeration capability) and also affects the characteristics of the finished products (brittleness, stickiness) and their stability during storage (oxidation) (O'Brien et al., 2003).

Currently, major changes in the production technology of confectionery products containing fats are taking place. This is due to the growing demands of consumers who are looking for products with high nutritional value, reduced calorific value, yet good sensory characteristics (Craig-Schmidt, 2006). The physical properties of fats depend not only on the fatty acid composition, but also on their location in the triacylglycerol molecules. Depending on the number of double bonds in the carbon chain, fatty acids can be divided into saturated, monounsaturated (monoenoic) and polyunsaturated (polyenoic). Fats containing saturated fatty acids are more resistant to oxidation and they are solid at room temperature; whereas fats containing unsaturated fatty acids are liquid. Fats containing saturated fatty acids, when consumed in excess amounts are not beneficial to our health, because they increase the level of "bad" LDL cholesterol, as well as increasing the risk of developing various circulatory system diseases (Żeglarska and Borejszo, 2001). A consumption of large amounts of saturated fatty acids can also increase the risk of the appearance of type 2 (B) diabetes (Hu et al., 2001).

Polyenoic acids are considered to be the most valuable fatty acid group in human nutrition. The majority of them, comononly called essential fatty acids (or EFAs), include the cis isomers of linoleic ( $n-6)$ and $\alpha$-linolenic acids ( $n-3)$, and other acids belonging to their families, i.e.: $\gamma$-linolenic and arachidonic acids (belonging to the linoleic acid family group) and eicosapentaenoic and docosahexaenoic acids (from the $\alpha$-linolenic acid family group).

Polyunsaturated fatty acids, including omega-3 acids are precursors of eicosanoids, which even in 
low concentrations exhibit a high biological activity, being responsible for numerous functions in tissues and organs.

The activity of omega- 3 acids is multidirectional. Among others, they can prevent atherosclerosis, high blood pressure and myocardial infarction as well as help to regulate blood pressure. These acids also positively affect the proper functioning of kidneys and gastrointestinal tract organs (Sudha et al., 2007). Widely conducted experiments have shown that the consumption of products containing saturated fatty acids and trans-configured fatty acids can be perceived as a risk factor for human health (Mozaffarian et al., 2006). Supplementation with high amounts of trans isomers of fatty acids increases the concentration of harmful LDL cholesterol in blood serum and lowers the concentration of healthy, HDL cholesterol.

Fats are especially vulnerable to adverse processes taking place during both technological processing (e.g. baking) and storage of food (Marmesat et al., 2009). The main processes which can cause a decrease in sensory properties and lower the nutritional value of fats and food products containing large amounts of fats include oxidation, hydrolysis of glycerides and formation of trans isomers of fatty acids (Aro, 2001; Pfeuffer and Schrezenmeir, 2006). During the process of pastry baking, significant amounts of acrylamide can be formed. Previous publications (Amrein et al., 2004; Gökmen et al., 2007) point out the influence of the composition of raw materials, including the composition of used fat and the conditions of the baking process, namely temperature and air humidity on the formation of acrylamide in the product.

Therefore, the aim of this research was to determine the influence of the type of fat used (varying in its content of trans-configured fatty acids) and air humidity during the baking of shortbread pastries on the chosen properties of the lipid fraction extracted directly after the baking process from pastries prepared with the use of various types of fat.

\section{MATERIALS AND METHODS}

\subsection{Chemicals}

Potassium hydroxide, acetic acid (99.5\%), sodium thiosulphate, benzene, isooctane, chloroform, petroleum ether (bp. $40-60^{\circ} \mathrm{C}$ ), all being analytical

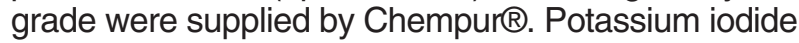
(analytical grade) was provided by by STANLAB. Starch and phenolphthalein were supplied by (Sigma).

\subsection{Raw materials used for the preparation of shortbread pastries}

For the production of shortbread pastries the following ingredients were used: fats including Akobake M100 (HT fat), Akobake Soft EAC (LT fat) produced by the AarhusKarlshamn company, "Kasia" margarine (TLE fat) produced by Unilever Poland
Ltd. Type 500 wheat flour was supplied by Diamant Int. Poland. Also fresh, A-grade eggs, white sugar "Królewski" Nordzucker Polska and baking powder by Delecta, containing disodium pyrophosphate and sodium bicarbonate, were used.

The fats used for baking the pastries were characterized by various physicochemical properties, different fatty acid compositions and different concentrations of trans configuration fatty acids. "Kasia" margarine (TLE fat) belonging to the trans-less fats group, in which the trans isomers of fatty acids content is below $1 \%$. The Akobake Soft EAC fat (LT fat) contains in its composition a maximum of $1 \%$ of trans configuration fatty acids and is classified as a low-trans fat; whereas the Akobake M100 fat (HT fat) is a high trans content fat - the trans isomers of fatty acids content in this fat is $15 \%$.

\subsection{Production of shortbread pastries}

Shortbread pastries were produced according to the following recipe: flour (149 g), fat $(99 \mathrm{~g})$, sugar $(99 \mathrm{~g})$, egg yolks (49 g), baking powder $(2 \mathrm{~g})$.

The baking of shortbread pastries was performed in an Ariston C 3 VP6 electric oven, at $180^{\circ} \mathrm{C}$ for 10 minutes, at three humidity levels: in dry air, at $70 \%$ and $90 \%$ humidity. After baking, the pastries were left to cool. Analyses regarding changes in the quality of lipid fraction were performed on the fat extracted from fresh products. For comparison, raw fats were subjected to a control.

\subsection{Fat extraction}

To obtain the lipid fraction from baked shortbread pastries, a ground sample of pastries was subjected to extraction with petroleum ether using the Soxtec Avanti 2055 apparatus by Foss Tecator Company.

\subsection{Analyses performed on raw fats and fats extracted from shortbread pastries}

In raw fats, as well as in lipid fractions extracted from baked pastries, the following quality determinants were assayed: acid value (EN ISO 660:1999 +A1:2005), peroxide value (Krełowska - Kułas M., 1993), conjugated dienes and trienes content (PN-EN ISO 3656:2002)

Furthermore, raw fats and fats extracted from the final products were subjected to thermodynamic analysis to establish a thermic profile of lipid fractions. Changes in the thermic profile of fats, depending on the type of fat used and air humidity during baking, were monitored using differential scanning calorimetry (DSC). Measurements were performed using a DSC 111 differential calorimeter, by Setaram Company (France). A steel crucible (batch type) with $40 \mathrm{mg}$ of freshly extracted fat sample was placed in a measurement cell and cooled to a temperature of $-40^{\circ} \mathrm{C}$. The sample was heated from $-40^{\circ} \mathrm{C}$ to $+60^{\circ} \mathrm{C}$ with a speed of $3^{\circ} \mathrm{C} \mathrm{min}^{-1}$. The applied 
temperature range allowed for the observation of the presence of separate fractions of studied fats. The reference sample was an empty cell. In the heating stage the melting profiles of the studied lipid fractions were recorded as peaks on the endothermic curves. The resulting field area of peaks was used for the calculation of the transformation enthalpy $\Delta \mathrm{H}$ (expressed in $\mathrm{J} \mathrm{g}^{-1}$ ) of temperatures from the beginning of melting $\left(T_{\text {onset }}\right)$, maximum of melting $\left(T_{\max }\right)$ and the end of the melting process $\left(T_{\text {offset }}\right)$ and were recorded for the given fractions of fat (expressed in ${ }^{\circ} \mathrm{C}$ ).

\subsection{Statistical analysis}

All the assays were carried out in triplicate for each type of fat and the results were averaged. Statistical significance of the results was determined at $p<0.05$.

\section{RESULTS AND DISCUSSION}

The aim of performed experiments was to determine the influence of fat and air humidity during the baking of shortbread pastries on the changes in the quality of the lipid fraction extracted from shortbread pastries directly after baking.

During the baking of pastry products one can expect the formation of various derivatives from lipids, namely acids, peroxides, hydroxyacids, ketones and aldehydes (Achremowicz and Korus, 2007). The following indicators were used for the examination of the changes taking place in the lipid fractions in the baking process: acid value, peroxide value, conjugated dienes and trienes contents and changes in their melting profiles.
The acid value (AV) of raw fats used for baking ranged from 0.06 to $0.11 \mathrm{mg} \mathrm{KOH}$ per gram of fat. The lowest value for AV was found for LT fat, and the highest value was found for HT fat (Fig. 1). The values obtained for $A V$ indicate a high freshness of the fats used (Ali Rehab and El Anany, 2012). The lipid fractions extracted from the pastries directly after baking, regardless of air humidity in the baking process, presented higher values for AV, compared with the results obtained for raw fats. These AV values exceeded several times the permitted value of $0.3 \mathrm{mg} \mathrm{KOH} \mathrm{g}{ }^{-1}$. This shows a significant increase in the degree of hydrolysis of the fats used for baking in the examined baking conditions. The greatest tendency to hydrolyze was observed in lipid fractions from products prepared in air with a humidity of $70 \%$ and in dry air. For fats from pastries baked in dry air, values varied from $0.85 \mathrm{mg} \mathrm{KOH} \mathrm{g}^{-1}$ of fat (LT fat) to $0.91 \mathrm{mg} \mathrm{KOH}$ $\mathrm{g}^{-1}$ of fat (TLE fat). For fats obtained from pastries baked in $70 \%$ air humidity, the acid number was on average on a level of $1.02 \mathrm{~g} \mathrm{KOH} \mathrm{g}^{-1}$ of fat. In fats from pastries baked in $90 \%$ air humidity, a lower tendency to hydrolyze was observed, compared to other conditions. For TLE fat and HT fat, AV values were 0.80 and $0.69 \mathrm{mg} \mathrm{KOH} \mathrm{g}^{-1}$ of fat, respectively. The greatest hydrolysis tendency in these conditions was observed in LTE fat.

The values obtained for acid value (Fig. 1) show that the greatest tendency to hydrolyze, regardless of air humidity during baking, was exhibited by the lipid fraction extracted from pastries prepared using LTE fat. The smallest change in the degree of hydrolysis, when baking at $90 \%$ air humidity, was observed in the lipid fraction extracted from pastries with HT fat. Judging by these values, it can

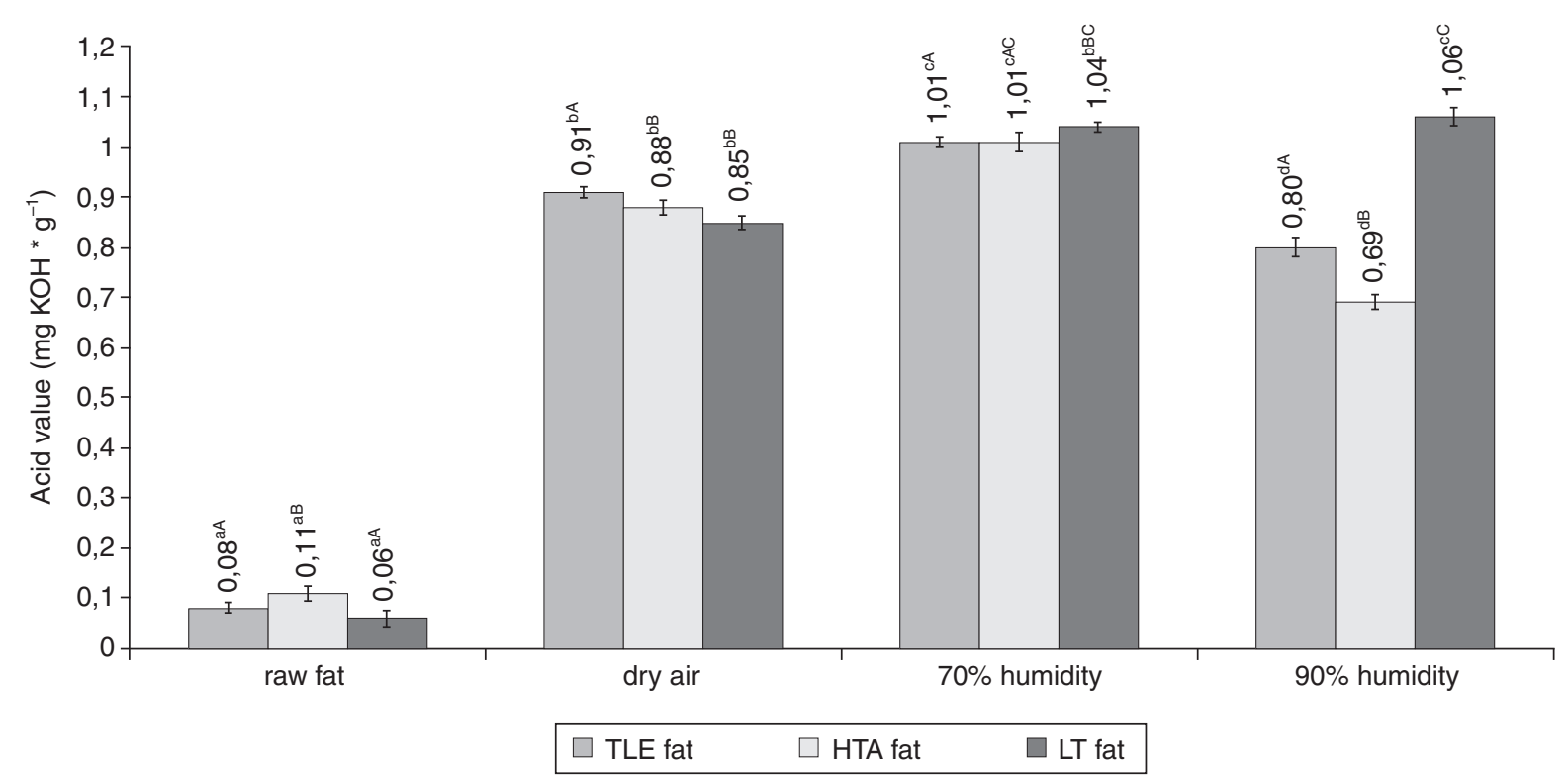

Figure 1

Changes of acid value of the lipid fraction extracted from shortbread pastries depending on type of fat and air humidity in baking.

Values within each row marked with small letter indexes differ significantly $(p \leq 0.05)-$ comparison of changes in different air humidity for a given type of fat. Values within each row marked with capital letter indexes differ significantly $(p \leq 0.05)-$ comparison of different types of fat after a certain air humidity. 
be concluded that the humidity of air during baking and the kind of fat used significantly influence $(p<0.05)$ the degree of hydrolysis of the fats.

Air humidity maintained during the baking process of shortbread pastries can influence the AV values of the fats used (Fig. 1). It can be observed that the lipid fractions extracted from products obtained in air with $70 \%$ humidity had higher values of acidity (on average by $16 \%$ ) than products baked in dry air.

TLE fat and HT fat extracted from pastries baked in air with $90 \%$ humidity showed lower AV values than those extracted from pastries obtained in dry air (by 12 and 21\%, respectively), and 70\% air humidity (by 21 and 33\%, respectively). This indicates that transless (TLE) and high-trans (HT) fats showed lower susceptibility to hydrolysis in high air humidity conditions (90\%). By contrast, the lipid fractions obtained from shortbread pastries baked with the use of LT fat showed an increase in AV when air humidity during baking was also increased (Fig. 1).

In figure 2, the influence of the conditions used during the baking process on the changes in the peroxide value (POV) of the lipid fraction extracted from the product is shown.

POV is usually used to measure the oxidative rancidity of an oil or fat (Raziq et al., 2012). The POV values of the raw fats used for baking shortbread pastries were in accordance with the standards, and they did not exceed $5 \mathrm{mmol} \mathrm{O}_{2} \mathrm{~kg}^{-1}$ of fat. For TLE fat and LT fat peroxide values were 0.12 and $0.01 \mathrm{mmol} \mathrm{O}_{2} \mathrm{~kg}^{-1}$ of fat, respectively. In HT fat no peroxides were observed. The conditions of the baking process (i.e., high temperature, air humidity), significantly altered the state of oxidation of the lipid fraction components. It was reflected by an increase in POV in the lipid fractions extracted from the products after baking. The lowest change in the oxidation of lipids was observed in the lipid fraction extracted from cookies immediately after baking in dry air (Fig. 2). The highest POV (1.14 mmol $\mathrm{O}_{2} \mathrm{~kg}^{-1}$ of product) was noticed for $\mathrm{HT}$ fat (containing $15 \%$ trans isomers of fatty acids) and the lowest (about 2 times higher when compared to raw fat), TLE fat (with no trans isomers of fatty acids) accounting for $0.26 \mathrm{mmol} \mathrm{O}_{2} \mathrm{~kg}^{-1}$ of product.

The increase in air humidity in the baking process of up to $70 \%$ caused the lipid fractions to be characterized by higher values of POV than those obtained from products baked in dry air. The biggest change in the degree of oxidation in general was observed in the lipid fraction extracted from cookies made with TLE fat, baked in $70 \%$ and $90 \%$ of air humidity. The POV of the lipid fraction of the above-mentioned fat, extracted from products baked in $90 \%$ of air humidity was 8.3 times higher compared to that obtained in dry air and 2.2 times higher than the peroxide value of the lipid fraction from products baked in air with $70 \%$ humidity.

The lipid fractions extracted from pastries baked in $90 \%$ air humidity with the use of HT fat and LT fat, had POV values 1.6 and 1.1 times lower than POV of lipid fractions obtained from pastries baked in air with $70 \%$ humidity. In contrast, lipid fractions from cookies baked with the use of TLE fat had POV 2.2 times higher when baked in 90\% air humidity, than when baked in $70 \%$ air humidity (Fig. 2). It can be observed that the kind of fat used for baking can influence the number of created peroxides

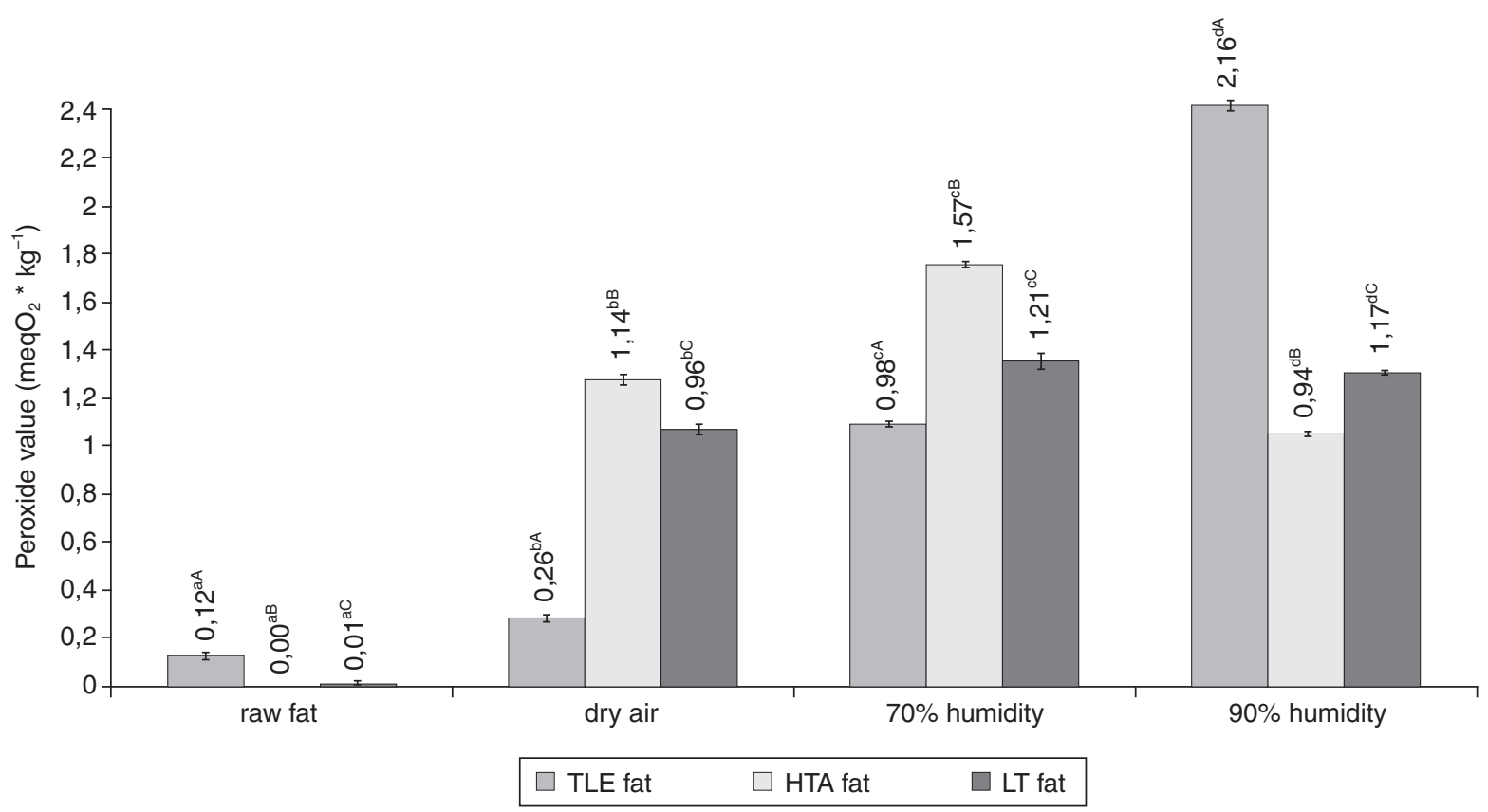

Figure 2

Changes of the peroxide value of the lipid fraction extracted from shortbread pastries depending on type of fat and air humidity in baking Values within each row marked with small letter indexes differ significantly $(p \leq 0.05)$ - comparison of changes in different air humidity for a given type of fat. Values within each row marked with capital letter indexes differ significantly $(p \leq 0.05)-$ comparison of different types of fat after a certain air humidity. 
in shortbread pastries obtained in increased air humidity. Increasing air humidity can also enhance the amount of oxidation products in the final product.

The correlation coefficients for POV and AV in the lipid fractions extracted from products baked in various air humidity values were positive, with an increase in POV which was simultaneous to an increase in AV for HT and LT fats. The correlation coefficients for these fats were 0.95 and 0.97 , respectively. The lipid fractions from the products obtained with the use of TLE fat had negative value for this correlation coefficient, which was -0.63. In case of this fat an increase in POV with a simultaneous decrease in AV took place, while air humidity used during baking was increased.

The next parameter, determining the degree of oxidation of fats was the contents of conjugated dienes (CD) and trienes (CT). The process of baking shortbread pastries caused significant changes in the contents of conjugated structures in the lipid fractions extracted from the products (Fig. $3 a$ and $3 b$ ). A simultaneous drop in contents of both CD and CT was characteristic of the lipid fractions obtained from the products based on LT and TLE fats, which was extracted from pastries baked in dry air and in humidity of $70 \%$ and $90 \%$.

In all the baking conditions examined, a decrease in CD and CT contents was observed, especially for TLE an LT fats, compared to raw fat. In the case of HT fat a slight increasing tendency $(p<0.05)$ was observed. Thus, the baking process did not cause a drastic increase in CD and CT contents, and even a decrease in these contents was observed. Surprisingly high was the content of CD in TLE fat, which did not contain trans isomers of fatty acids (with conjugated configuration). In other fats their significant amounts seem to be justified. The baking process causes a decrease in the amounts of these structures, which consequently can cause a lowering in contents of trans isomers of fatty acids.

a)

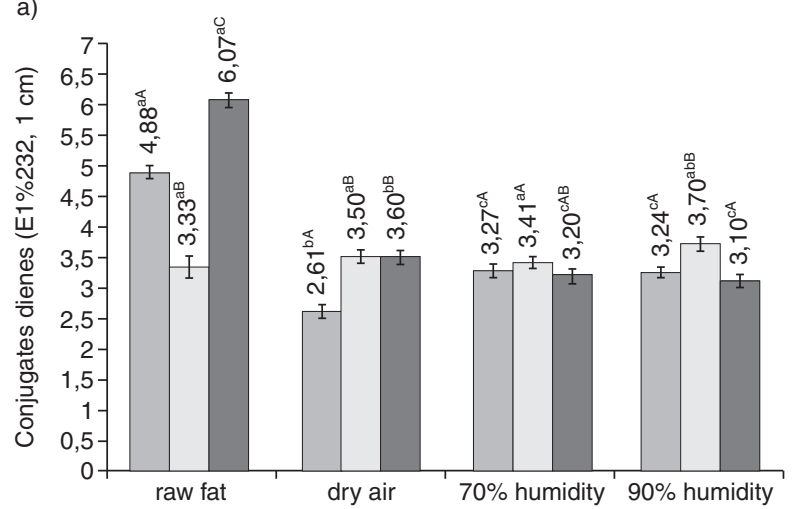

The highest increase in CD content was observed in the lipid fraction form cookies obtained with HT fat baked in $90 \%$ air humidity.

A significant content of CT was observed in raw HT and LT fats. TLE fat had a significantly lower $(p<0.05)$ amount of CT. The baking process caused a decrease in CT content, positively correlated with increasing air humidity in the case of those fats in which the initial CT amount was high (LT and HT). In the case of TLE fat a decrease in CT content was reversely correlated with air humidity maintained during the baking process, however, on average, the percentage of decrease in this content was the greatest of all the studied fats.

Significant differences $(p<0.05)$ were noticed when comparing the correlation coefficients between POV and an amount of CD of products made with the use of different fats. TLE fat had a positive correlation coefficient between those parameters $(0.75$, which indicated a simultaneous increase in the amounts of peroxides and conjugated dienes). Those correlation coefficients for HT and LT fats were negative and amounted to -0.98 and -0.93 , respectively. Which can indicate that trans fats are less susceptible to oxidation.

One of the methods to determine changes occurring in fats in the process of shortbread pastry baking was the melting profile characterization as determined by the differential scanning calorimetry (DSC), expressed in temperature and melting enthalpy of individual fractions, resulting from changes in the packing of the crystalline network of the lipid fraction. The degree of fat oxidation and hydrolysis is also reflected in the changes in their melting properties (Gloria and Aguilera, 1998; Tan and Che Man, 1999).

In figure 4 and in tables 1-3, the values of melting enthalpies of the lipid fractions of raw fats and the fats extracted from baked products as well as their melting temperatures i.e. the beginning of b)

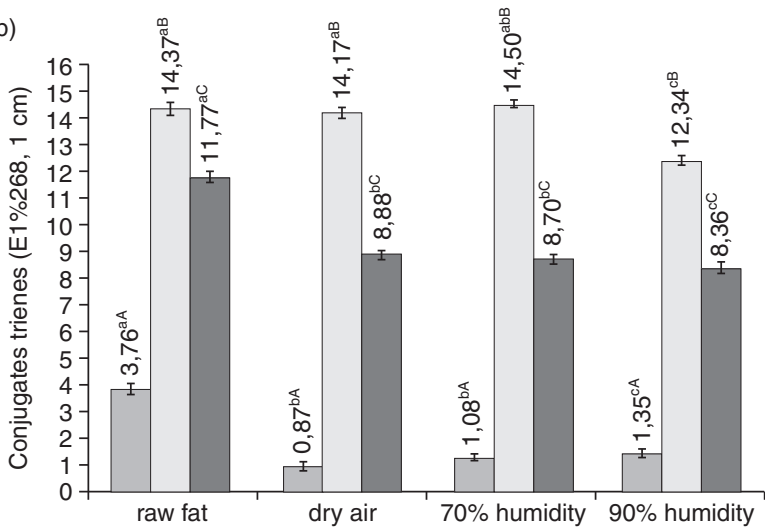

$$
\square \text { TLE fat } \quad \square \text { HTA fat } \quad \square \text { LT fat }
$$




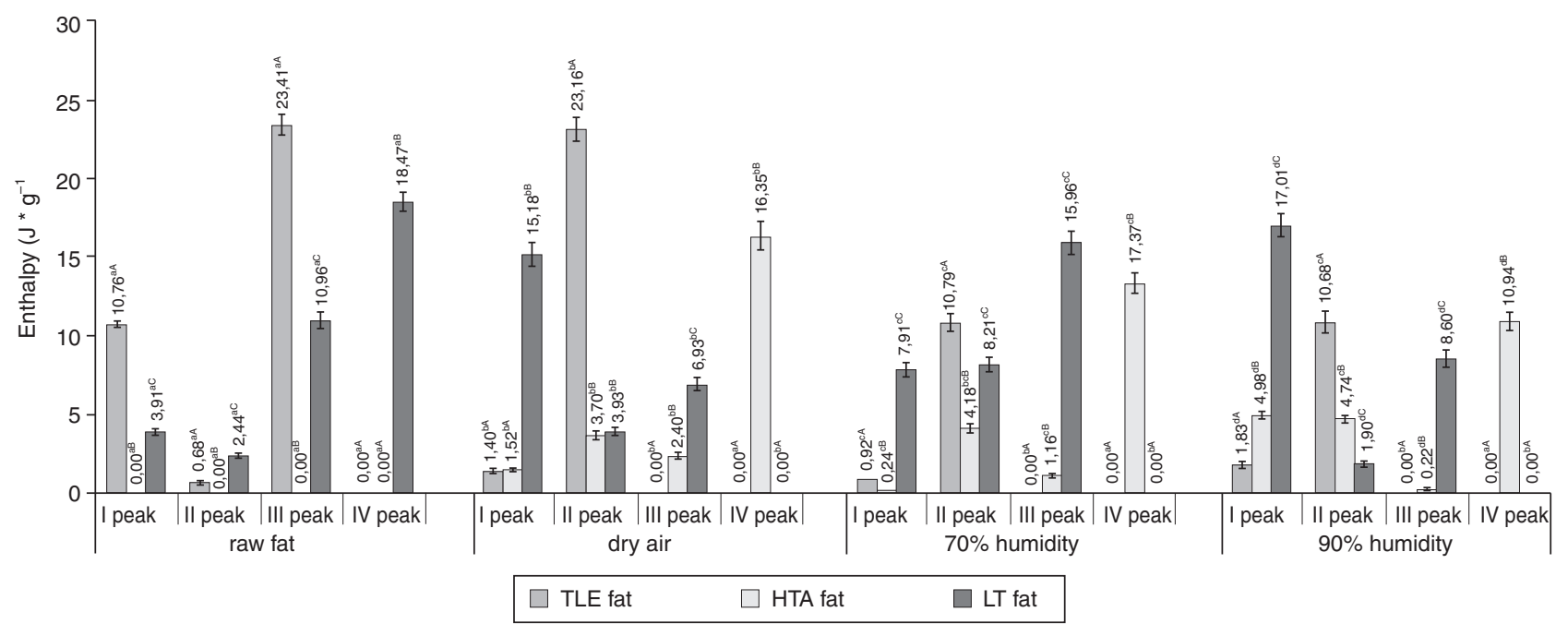

Figure 4

Change of polymorphism of the lipid fraction of products after baking expressed as the magnitude of enthalpy of melting depending on type of fat and air humidity in baking. Values within each row marked with small letter indexes differ significantly $(p \leq 0.05)-$ comparison of changes in different air humidity for a given type of fat. Values within each row marked with capital letter indexes differ significantly $(p \leq 0.05)$ - comparison of different types of fat after a certain air humidity.

the process ( $\left.T_{\text {onset }}\right)$, maximum $\left(T_{\max }\right)$ and the end of the process $\left(\mathrm{T}_{\text {offset }}\right)$ are presented.

The DSC analysis of raw fats indicated a noticeable differentiation in the quantities of lipid fractions and their melting temperatures depending on the kind of fat used in the baking process. The smallest amount of lipid fractions was observed in HT fat - only one peak was present on the endothermic curve (Fig. 4, Fig. 5b, Tab. 2). On the other hand, the other two fats had bigger

Table 1

Change of polymorphism of the lipid fraction extracted from product made using the TLE fat in the recipe, expressed in the magnitude of melting point temperature, depending on air humidity during baking

\begin{tabular}{|c|c|c|c|c|c|c|}
\hline Fat type & $\begin{array}{c}\text { Air humidity } \\
(\%)\end{array}$ & $\begin{array}{c}\text { Peak } \\
\text { number }\end{array}$ & $\mathrm{T}_{\text {onset }}\left({ }^{\circ} \mathrm{C}\right)$ & $\mathrm{T}_{\max }\left({ }^{\circ} \mathrm{C}\right)$ & $\mathrm{T}_{\text {offset }}\left({ }^{\circ} \mathrm{C}\right)$ & $\begin{array}{c}\mathrm{T}_{\text {offset }}-\mathrm{T}_{\text {onset }} \\
\left({ }^{\circ} \mathrm{C}\right)\end{array}$ \\
\hline \multirow[t]{4}{*}{ Raw fat } & \multirow[t]{4}{*}{-} & I & $-21.10^{\mathrm{aA}} \pm 1.10$ & $-15.75^{\mathrm{aA}} \pm 0.78$ & $-9.89^{\mathrm{aA}} \pm 0.99$ & $11.21^{\mathrm{aA}} \pm 1.00$ \\
\hline & & II & $-1.96^{\mathrm{aB}} \pm 0.89$ & $-0.25^{\mathrm{aB}} \pm 0.65$ & $1.83^{\mathrm{aB}} \pm 0.90$ & $3.79^{\mathrm{aB}} \pm 0.90$ \\
\hline & & III & $25.99^{\mathrm{aC}} \pm 0.99$ & $32.70^{\mathrm{aC}} \pm 1.10$ & $39.24^{\mathrm{aC}} \pm 1.15$ & $13.25^{\mathrm{aA}} \pm 1.15$ \\
\hline & & IV & - & - & - & - \\
\hline \multirow{12}{*}{$\begin{array}{l}\text { Fat extracted } \\
\text { from product }\end{array}$} & \multirow[t]{4}{*}{ dry } & 1 & $-6.08^{\mathrm{bA}} \pm 0.65$ & $-3.76^{\mathrm{bA}} \pm 0.49$ & $-0.70^{\mathrm{bA}} \pm 0.10$ & $\mathbf{5 . 3 8 ^ { \mathrm { bA } }} \pm 0.40$ \\
\hline & & II & $23.28^{\mathrm{bB}} \pm 0.96$ & $34.17^{\mathrm{bB}} \pm 0.79$ & $44.71^{\mathrm{bB}} \pm 1.00$ & $21.43^{\mathrm{bB}} \pm 1.00$ \\
\hline & & III & - & - & - & - \\
\hline & & IV & - & - & - & - \\
\hline & \multirow[t]{4}{*}{70} & 1 & $-6.02^{\mathrm{bA}} \pm 0.99$ & $-3.27^{\mathrm{bA}} \pm 1.00$ & $-0.43^{\mathrm{bA}} \pm 0.60$ & $5.59^{\mathrm{bA}} \pm 0.75$ \\
\hline & & II & $29.68^{\mathrm{CB}} \pm 1.10$ & $35.95^{\mathrm{bB}} \pm 1.15$ & $46.15^{\mathrm{bB}} \pm 1.25$ & $16.47^{\mathrm{CB}} \pm 1.20$ \\
\hline & & III & - & - & - & - \\
\hline & & IV & - & - & - & - \\
\hline & \multirow[t]{4}{*}{90} & 1 & $-7.57^{\mathrm{bA}} \pm 1.10$ & $-4.27^{\mathrm{bA}} \pm 0.99$ & $-0.37^{\mathrm{bA}} \pm 0.90$ & $7.02^{\mathrm{bA}} \pm 1.10$ \\
\hline & & II & $27.62^{\mathrm{cB}} \pm 1.12$ & $34.57^{\mathrm{bB}} \pm 1.15$ & $40.87^{\mathrm{cB}} \pm 1.22$ & $13.25^{\mathrm{dB}} \pm 1.18$ \\
\hline & & III & - & - & - & - \\
\hline & & IV & - & - & - & - \\
\hline
\end{tabular}

$T_{\text {onset }}$ - temperature of start of melting of the given polymorphic form. $T_{\max }$ - maximal temperature of melting of the given polymorphic form. $T_{\text {offset }}$ - temperature of end of melting of the given polymorphic form. Data are presented as the mean $\pm S D(n \geq 3)$. Values within each row marked with small letter indexes differ significantly $(p \leq \leq 0.05)$ - comparison of temperatures of certain polymorphic form in different air humidity for a given type of fat. Values within each row marked with capital letter indexes differ significantly $(p \leq 0.05)$ comparison of temperatures of polymorphic forms of a certain type of fat after a certain air humidity. 
Table 2

Change of polymorphism of the lipid fraction extracted from product made using the HT fat in the recipe, expressed in the magnitude of melting point temperature, depending on air humidity during baking

\begin{tabular}{|c|c|c|c|c|c|c|}
\hline Fat type & $\begin{array}{c}\text { Air humidity } \\
(\%)\end{array}$ & $\begin{array}{c}\text { Peak } \\
\text { number }\end{array}$ & $\mathrm{T}_{\text {onset }}\left({ }^{\circ} \mathrm{C}\right)$ & $\mathrm{T}_{\max }\left({ }^{\circ} \mathrm{C}\right)$ & $\mathrm{T}_{\text {offset }}\left({ }^{\circ} \mathrm{C}\right)$ & $\begin{array}{c}T_{\text {offset }}-T_{\text {onset }} \\
\left({ }^{\circ} \mathrm{C}\right)\end{array}$ \\
\hline \multirow[t]{4}{*}{ Raw fat } & \multirow[t]{4}{*}{-} & 1 & $23.40^{a} \pm 0.99$ & $32.00^{a} \pm 1.00$ & $36.50^{a} \pm 1.25$ & $13.10^{a} \pm 1.11$ \\
\hline & & II & - & - & - & - \\
\hline & & III & - & - & - & - \\
\hline & & IV & - & - & - & - \\
\hline \multirow{12}{*}{$\begin{array}{l}\text { Fat extracted } \\
\text { from product }\end{array}$} & \multirow[t]{4}{*}{ dry } & I & $-12.09^{\mathrm{bA}} \pm 1.28$ & $-5.74^{\mathrm{bA}} \pm 1.22$ & $-2.02^{\mathrm{bA}} \pm 1.15$ & $10.07^{\mathrm{bA}} \pm 1.20$ \\
\hline & & ॥ & $-0.79^{\mathrm{aB}} \pm 1.35$ & $3.06^{\mathrm{aB}} \pm 1.25$ & $12.28^{\mathrm{aB}} \pm 1.05$ & $13.07^{\mathrm{aB}} \pm 1.20$ \\
\hline & & III & $17.74^{\mathrm{aC}} \pm 1.11$ & $20.30^{\mathrm{aC}} \pm 1.14$ & $24.89^{\mathrm{aC}} \pm 0.98$ & $7.15^{\mathrm{ac}} \pm 1.05$ \\
\hline & & IV & $25.80^{\mathrm{aD}} \pm 1.11$ & $35.53^{\mathrm{aD}} \pm 1.35$ & $42.73^{\mathrm{aD}} \pm 1.45$ & $16.93^{\mathrm{aD}} \pm 1.32$ \\
\hline & \multirow[t]{4}{*}{70} & I & $-8.98^{\mathrm{CA}} \pm 0.14$ & $-5.26^{\mathrm{bA}} \pm 0.78$ & $-3.04^{\mathrm{bA}} \pm 0.99$ & $5.94^{\mathrm{cA}} \pm 0.58$ \\
\hline & & II & $-2.11^{\mathrm{aB}} \pm 1.35$ & $2.58^{\mathrm{aB}} \pm 1.20$ & $12.59^{\mathrm{aB}} \pm 1.10$ & $14.70^{\mathrm{aB}} \pm 1.20$ \\
\hline & & III & $17.80^{\mathrm{aC}} \pm 1.11$ & $19.76^{\mathrm{aC}} \pm 1.25$ & $23.39^{\mathrm{aC}} \pm 0.99$ & $5.59^{\mathrm{aA}} \pm 1.05$ \\
\hline & & IV & $24.69^{\mathrm{aD}} \pm 0.99$ & $35.21^{\mathrm{aD}} \pm 0.59$ & $42.62^{\mathrm{aD}} \pm 0.85$ & $17.93^{\mathrm{ac}} \pm 0.90$ \\
\hline & \multirow[t]{4}{*}{90} & I & $-17.53^{\mathrm{dA}} \pm 1.25$ & $-6.36^{\mathrm{bA}} \pm 1.09$ & $0.06^{\mathrm{bcA}} \pm 1.20$ & $17.59^{\mathrm{dA}} \pm 1.19$ \\
\hline & & II & $2.11^{\mathrm{aB}} \pm 1.00$ & $11.35^{\mathrm{bB}} \pm 1.03$ & $18.52^{\mathrm{bB}} \pm 0.98$ & $16.41^{\mathrm{baA}} \pm 1.05$ \\
\hline & & III & $22.38^{\mathrm{bC}} \pm 1.40$ & $24.71^{b c} \pm 1.23$ & $27.05^{\mathrm{abc}} \pm 1.25$ & $4.67^{\mathrm{baB}} \pm 1.34$ \\
\hline & & IV & $29.03^{\mathrm{bD}} \pm 0.90$ & $35.36^{\mathrm{aD}} \pm 1.00$ & $41.33^{\mathrm{aD}} \pm 1.15$ & $12.30^{\mathrm{bC}} \pm 1.09$ \\
\hline
\end{tabular}

$T_{\text {onset }}$ - temperature of start of melting of the given polymorphic form. $T_{\max }$ - maximal temperature of melting of the given polymorphic form. $T_{\text {offset }}$ - temperature of end of melting of the given polymorphic form. Data are presented as the mean $\pm S D(n \geq 3)$. Values within each row marked with small letter indexes differ significantly ( $\mathrm{s} \leq 0.05)$ - comparison of temperatures of certain polymorphic form in different air humidity for a given type of fat. Values within each row marked with capital letter indexes differ significantly ( $p \leq 0.05)$ comparison of temperatures of polymorphic forms of a certain type of fat after a certain air humidity.

polymorphic diversity, i.e. TLE fat - three peaks (Fig. 5a, Tab. 1) and LT fat - four peaks (Fig. 4, Fig. 5c, Tab. 3). The lipid fractions of LT and HT fats melted in the range of $T_{\max }$ between 22 and $39^{\circ} \mathrm{C}$, and TLE fat around $-16^{\circ} \mathrm{C}$.

The DSC results obtained confirm that baking conditions (i.e. air humidity) also influence the qualitative changes in lipid fractions extracted from the final products, as compared to raw fats, a confirmation of which is again a big differentiation of the polymorphic forms present, i.e. both their quantities (melting enthalpies $\Delta \mathrm{H}$, Fig. 4) and melting temperatures (Tab. 1-3), depend on the type of fat used and the air humidity maintained during the baking process.

The biggest changes in the crystallographic grid after the baking process, compared to raw fats, were noticed in $\mathrm{HT}$ fat (Fig. 4, Fig. 5b, Table 2). Besides fractions with melting temperatures around $32^{\circ} \mathrm{C}$ present in raw fats, three additional forms with lower melting temperatures were observed, i.e. around 20,3 and $-5^{\circ} \mathrm{C}$. The analysis of polymorphic changes occurring in the aforementioned fat, depending on air humidity during baking indicated a variation in the quantities of various fractions and their melting temperatures.

Comparing the amounts of lipid fractions extracted from the pastries made with HT fat, baked under different air humidity conditions, made way for a claim that an increase in air humidity from dry to $70 \%$ and finally $90 \%$ caused an increase in the quantities of lipid fractions with low melting temperatures (presented Fig. 4, Fig. 5b and Table 2 as peaks I and II), on average by $84 \%$ and $13 \%$, with a simultaneous decrease in the contents of fractions with higher melting temperatures (in Fig. 4 and Table 2 peaks III and IV), by $71 \%$ and $25 \%$, respectively.

The analysis of changes in the polymorphism of LT fat indicated that an increase in air humidity from dry to $70 \%$ caused a decrease in the content of the lipid fraction (peak I) by about 45\% (Fig. 4, Fig. 5c, Table 3), with a simultaneous increase in its melting temperature. In the case of fractions marked as peaks II and III, an increase in air humidity from dry to $70 \%$ caused, on average, a 2 -fold increase in their quantities and a decrease in their melting temperatures $\left(T_{\max }\right)$ by $12 \%$ and $14 \%$, respectively (Table 3). A further increase in air humidity during the baking of shortbread pastries to $90 \%$ resulted in a decrease in the amounts of these fractions (peaks II and III) by $77 \%$ and $46 \%$, respectively, compared to cookies baked in dry air. At the same time, the melting temperatures increased by about $5 \%$ for both fractions presented as peaks II and III (Fig. 4 and Table 3). 
Table 3

Change of polymorphism of the lipid fraction extracted from product made using the TL fat in the recipe, expressed in the magnitude of melting point temperature, depending on air humidity during baking

\begin{tabular}{|c|c|c|c|c|c|c|}
\hline Fat type & $\begin{array}{c}\text { Air humidity } \\
(\%)\end{array}$ & $\begin{array}{c}\text { Peak } \\
\text { number }\end{array}$ & $\mathrm{T}_{\text {onset }}\left({ }^{\circ} \mathrm{C}\right)$ & $\mathrm{T}_{\max }\left({ }^{\circ} \mathrm{C}\right)$ & $\mathrm{T}_{\text {offset }}\left({ }^{\circ} \mathrm{C}\right)$ & $\begin{array}{c}\mathrm{T}_{\text {offset }}-\mathrm{T}_{\text {onset }} \\
\left({ }^{\circ} \mathbf{C}\right)\end{array}$ \\
\hline \multirow[t]{4}{*}{ Raw fat } & \multirow[t]{4}{*}{-} & 1 & $-7.90^{\mathrm{aA}} \pm 1.11$ & $0.49^{\mathrm{aA}} \pm 1.20$ & $4.45^{\mathrm{aA}} \pm 0.99$ & $12.35^{\mathrm{aA}} \pm 0.79$ \\
\hline & & II & $9.05^{\mathrm{aA}} \pm 0.58$ & $13.11^{\mathrm{aB}} \pm 0.15$ & $15.65^{\mathrm{aB}} \pm 0.25$ & $6.60^{\mathrm{aB}} \pm 0.50$ \\
\hline & & III & $19.13^{\mathrm{aB}} \pm 1.15$ & $22.74^{\mathrm{aC}} \pm 1.05$ & $27.11^{\mathrm{aC}} \pm 1.35$ & $7.98^{\mathrm{aB}} \pm 1.20$ \\
\hline & & IV & $31.88^{\mathrm{aC}} \pm 0.99$ & $39.12^{\mathrm{aD}} \pm 1.01$ & $45.57^{\mathrm{aD}} \pm 1.15$ & $13.69^{\mathrm{aA}} \pm 1.22$ \\
\hline \multirow{12}{*}{$\begin{array}{l}\text { Fat extracted } \\
\text { from product }\end{array}$} & \multirow{4}{*}{ dry } & I & $-8.37^{\mathrm{aA}} \pm 1.25$ & $3.30^{\mathrm{bA}} \pm 1.11$ & $7.80^{\mathrm{bA}} \pm 1.02$ & $16.17^{\mathrm{bA}} \pm 0.99$ \\
\hline & & II & $11.82^{\mathrm{bB}} \pm 0.99$ & $17.58^{\mathrm{bB}} \pm 0.85$ & $22.07^{\mathrm{bB}} \pm 1.05$ & $10.25^{\mathrm{bB}} \pm 1.12$ \\
\hline & & III & $28.70^{\mathrm{bC}} \pm 0.98$ & $39.62^{\mathrm{bC}} \pm 0.35$ & $46.38^{\mathrm{bC}} \pm 0.28$ & $17.68^{\mathrm{bA}} \pm 1.00$ \\
\hline & & IV & - & - & - & - \\
\hline & \multirow[t]{4}{*}{70} & I & $-10.15^{\mathrm{bA}} \pm 0.25$ & $6.82^{\mathrm{cA}} \pm 0.45$ & $5.75^{\mathrm{aA}} \pm 0.99$ & $15.90^{\mathrm{cbA}} \pm 1.00$ \\
\hline & & II & $8.83^{\mathrm{aB}} \pm 0.24$ & $15.41^{\mathrm{cB}} \pm 0.18$ & $20.72^{\mathrm{CB}} \pm 0.21$ & $11.89^{\mathrm{cB}} \pm 0.30$ \\
\hline & & III & $27.71^{\mathrm{cbC}} \pm 1.25$ & $34.05^{\mathrm{cC}} \pm 1.30$ & $45.68^{\mathrm{cC}} \pm 1.00$ & $17.97^{\mathrm{bA}} \pm 1.15$ \\
\hline & & IV & - & - & - & - \\
\hline & \multirow[t]{4}{*}{90} & I & $-8.78^{\mathrm{abA}} \pm 1.30$ & $4.19^{\mathrm{bA}} \pm 1.25$ & $8.90^{\mathrm{cbA}} \pm 1.21$ & $17.68^{\mathrm{dbcA}} \pm 1.22$ \\
\hline & & II & $13.61^{\mathrm{cbB}} \pm 1.25$ & $18.57^{\mathrm{dbB}} \pm 1.22$ & $23.84^{\mathrm{dB}} \pm 1.20$ & $10.23^{\mathrm{dbB}} \pm 1.20$ \\
\hline & & III & $31.61^{\mathrm{dC}} \pm 1.12$ & $41.69^{\mathrm{dC}} \pm 1.30$ & $48.81^{\mathrm{dC}} \pm 1.19$ & $17.20^{\mathrm{bA}} \pm 1.22$ \\
\hline & & IV & - & - & - & - \\
\hline
\end{tabular}

$T_{\text {onset }}$ - temperature of start of melting of the given polymorphic form. $T_{\max }$ - maximal temperature of melting of the given polymorphic form. $T_{\text {offset }}$ - temperature of end of melting of the given polymorphic form. Data are presented as the mean $\pm S D(n \geq 3)$. Values within each row marked with small letter indexes differ significantly ( $p \leq 0.05)$ - comparison of temperatures of certain polymorphic form in different air humidity for a given type of fat. Values within each row marked with capital letter indexes differ significantly ( $p \leq 0.05$ ) comparison of temperatures of polymorphic forms of a certain type of fat after a certain air humidity.

In the case of TLE fat, baking conditions caused about a 10-fold decrease in the content of fraction with the lowest $T_{\max }$, compared to raw fat, with a simultaneous increase in its melting temperature, i.e. from around $-15^{\circ} \mathrm{C}$ to around $-3^{\circ} \mathrm{C}$. A quantity of a fraction which melts in higher temperatures, i.e. about $35^{\circ} \mathrm{C}$, decreased by about 2 -fold while its temperature $\mathrm{T}_{\max }$ increased slightly, on average by $3^{\circ} \mathrm{C}$. An increase in air humidity from dry air to $70 \%$ and finally $90 \%$ caused a decrease in the amounts of both lipid fractions extracted from the final products by $34 \%$ in the case of the fraction marked as peak I, and by $53 \%$ in the case of fractions presented as peak II (Fig. 4, Fig. 5a, Table 1). It is worth noting that air humidity during the baking of cookies did not significantly influence the melting temperatures of the lipid fractions from TLE fat (Tab. 1).

The difference in $\mathrm{T}_{\text {offset }}$ and $\mathrm{T}_{\text {onset }}$ temperatures indicates a high degree of arrangement and homogeneity of the crystallographic grid of the lipid fraction. In the case of lipid fractions extracted from products with LT and HT fats, baked in various humidity conditions, a worse homogeneity was observed, as compared to lipid fractions from TLE containing products. This is indicated by higher differences between $T_{\text {offset }}$ and $T_{\text {onset }}$ temperature values. This effect is a reflection of the fact that in lipid fractions from HT and $\mathrm{LT}$ fat containing products, a higher variation in hydrolysis products can be found.

As of yet, no similar results have been published in the literature so it is difficult to compare our results to other data. However, the significance of our research is strengthened by the importance of the directions of changes occurring in lipid fractions of pastry products during baking, which influences the quantity of formed acrylamide. Yet unpublished results regarding this aspect will confirm that the kind of fat (trans-containing or trans-less) and air humidity maintained during baking significantly influence the amount of acrylamide formed in a final product, which is why it was so important to evaluate how the kind of fat and air humidity affect the changes taking place in lipid fractions extracted from baked shortbread pastries.

\section{CONCLUSIONS}

The experiments were performed with the aim of establishing how the variety of fat used and the air humidity conditions during baking influence the quality of the lipid fractions extracted from baked shortbread pastries. 

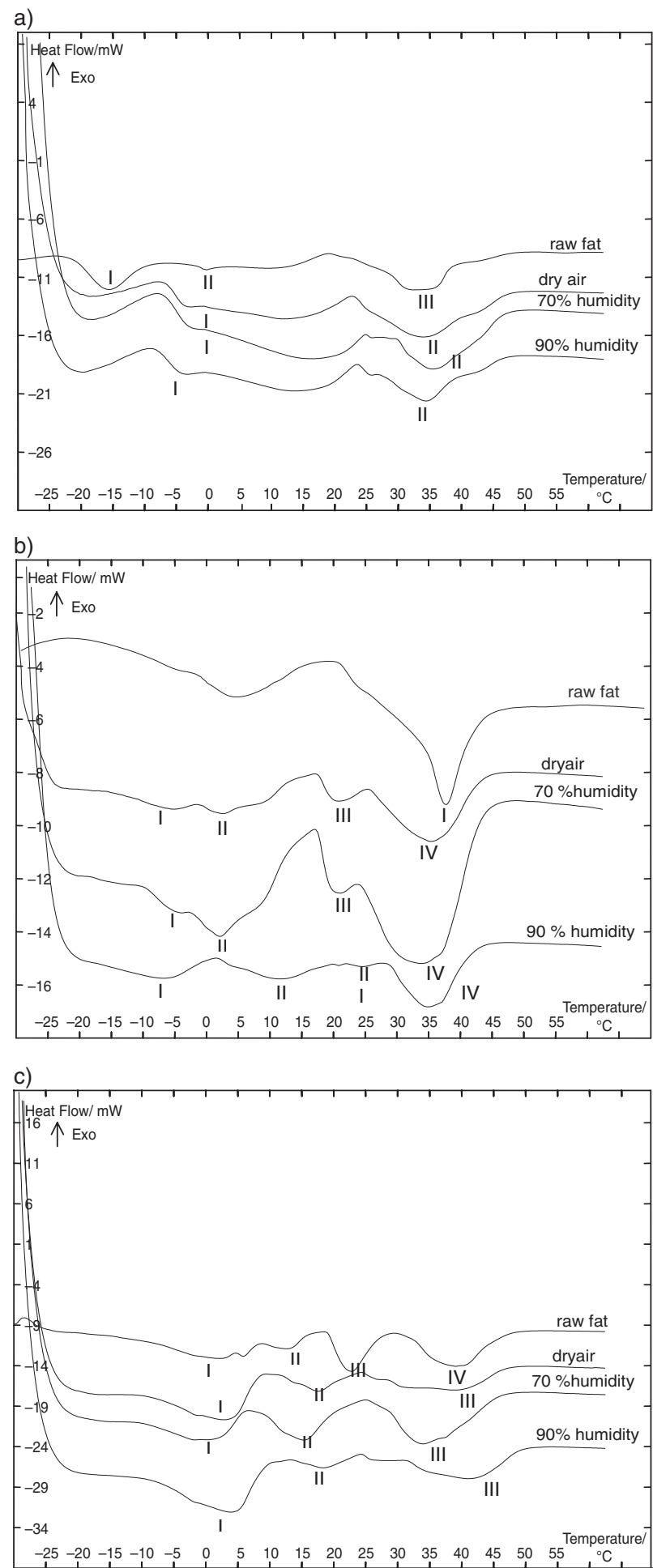

Figure 5

Endotherms of melting of fat: TLE (a), HT (b) and LT (c) depending on the air humidity in the baking process of shortbread pastries.

In the case of TLE and HT fats, the smallest susceptibility to hydrolysis was observed in lipid fractions extracted from products baked in 90\% air humidity, while for LT, it was dry air. Thermal analysis (DSC) allowed for the determination that an increase in air humidity during baking caused a decrease in melting temperature of the lipid fractions characterized by the lowest values of melting temperatures $\left(T_{\max }\right)$, compared to dry air conditions. It can indirectly point to a presence in lipid fractions obtained from products baked in higher air humidity of products with a high degree of unsaturation, which are more susceptible to transformations. In conclusion, using high air humidity conditions, which are beneficial when trying to lower the quantity of formed acrylamide, unfavorably influences the degree of fat saturation, especially those with high degrees of unsaturation. For these types of fat it is advisable to use dry air conditions during the baking process.

\section{ACKNOWLEDGMENTS}

The authors thank the National Research and Development Centre for its financial support (Grant $\mathrm{R} 120086$ 06) of this research.

\section{REFERENCES}

Achramowicz B, Korus J. 2007. Potrzeba regulacji zawartości izomerów trans kwasów tluszczowych w żywności. Żywność, Nauka, Technologia, Jakość. 3, 5-14.

Ali Rehab FM, El Anany AM. 2012. Physicochemical studies on sunflower oil blended with cold pressed tiger nut oil during the deep frying process. Grasas Aceites. 63, 455-465.

Amrein T, Schobachler B, Escher F, Amadó R. 2004. Acrylamide in gingerbread: critical factors for formation and possible ways for reduction. J. Agric. Food Chem. 52, 4282-4288.

Aro A. 2001. Complexity of issue of dietary trans fatty acids. The Lancet 357, 732.

Craig-Schmidt MC. 2006. World- wide consumption of trans fatty acids. Atherosclerosis. 7, 1-4.

EN ISO 660:1999 +A1:2005

Gloria H, Aguilera JM. 1998. Assessment of the quality of heated oils by differential scanning calorimetry. $J$. Agric. Food Chem. 46, 1363-1368.

Gőkmen V, Ǒzge CA, Kőksel H. 2007. Effects of dough formula and baking conditions on acrylamide and hydroxymethylofurfural formation in cookies. Food Chem. 104, 1136-1142.

Hu FB, Manson JE, Stampfer MJ, Colditz G, Liu S, Solomon CG, Willet W. C. 2001. Diet, lifestyle, and the risk of type 2 diabets mellitus in women. J. Med. 345, 790-797.

Krełowska-Kułas M. 1993. Badania o jakości produktów spożywczych. Państwowe Wydawnictwo Ekonomiczne. Warszawa 79-80.

Manche-Rezzoug Z, Bouvier JM, Allan K, Patras C. 1998. Effect of principal ingredients on rheological behaviour of biscuit dough and on quality of biscuit. $J$. Food Eng. 35, 23-42.

Marmesat S, Morales A, Velasco J, Ruiz-Méndez MV, Dobarganes MC. 2009. Relationship between changes in peroxide value and conjugated dienes during oxidation of sunflower oils with different degree of unsaturation. Grasas Aceites 60, 155-160.

Mozaffarian D, Katan MB, Ascherio A, Stampfer MJ, Willet W. 2006. Trans fatty acids and cardiovascular disease. J. Med. 354, 1601-1613. 
O'Brien CM, Chapman D, Neville DP, Keogh MK, Arendt EK. 2003. Effect of varying the microencapsulation process on the functionality of hydrogenated vegetable fat in shortdough biscuits. Food Res. Int. 36, 215-221.

Pfeiffer M, Schrezenmeir J. 2006. Impact of trans fatty acids of ruminant origin compared with those from partially hydrogenated vegetable oils on $\mathrm{CHD}$ risk. Int. Dairy J. 16, 1383-1388.

PN-EN ISO 3656:2002 Oleje i tłuszcze roślinne oraz zwierzęce - Oznaczanie absorbancji w nadfiolecie wyrażonej jako ekstynkcja właściwa w świetle UV.

Raziq S, Anwar F, Mahmood Z, Shahid SA, Nadeem R. 2012. Characterization of seed oils from different varieties of watermelon [Citrullus lanatus (Thunb.)] from Pakistan. Grasas Aceites, 63, 365-372.
Sudha ML, Srivastava AK, Vetrimani R, Leelavathi K. 2007. Fat replacement in soft dough biscuits: Its implications on dough rheology and biscuit quality. $J$. Food Eng. 80, 922-930.

Tan CP, Che Man YB. 1999. Quantitative differential scanning calorimetric analysis for determining total polar compounds in heated oils. J. Am. Oil Chem. Soc. 76, 1047-1057.

Zoulias El, Oreopoulou V, Tzia C. 2002. Textural properties of low-fat cookies containing carbohydrate- or proteinbased fat replacers. J. Food Eng. 55, 337-342.

Żegarska Z., Borejszo Z. 2001. Trans fatty acid content of some food products in Poland. Food Lipids. 8, 271-279.

Recibido: 20/6/12 Aceptado: $4 / 12 / 12$ 